\title{
Sediment Management in East Lake, China: a Combined Bio-Physical and Socioeconomic Approach for Managing Sediments in a Polluted Lake System
}

\author{
Senlin Zhu ${ }^{1-3 *}$, Guolu Yang ${ }^{1,3}$, Jiangyu Dai ${ }^{2}$ \\ ${ }^{1}$ State Key Laboratory of Water Resources and Hydropower Engineering Science, Wuhan University, \\ Wuhan 430072, China \\ ${ }^{2}$ State Key Laboratory of Hydrology-Water resources and Hydraulic Engineering, Nanjing Hydraulic Research Institute, \\ Nanjing 210029, China \\ ${ }^{3}$ Sewage Sludge and Silt Research Centre, Wuhan University, \\ Wuhan 430072, China
}

Received: 7 August 2017

Accepted: 10 September 2017

\begin{abstract}
In large lakes, serious sedimentation and pollution of bottom sediments has occurred in China owing to the neglect of effective protection and management. Thus, sediment management, acting as an important aspect of lake management, should be performed in lake systems. The goal of this study was to determine sediment management framework, and take a physicochemical and socioeconomic approach for sediment management. Sediment quantity and quality analysis was developed, sources of sediment and associated contaminants were analyzed, and management methods such as the ecological water network, source control, and local dredging and sediment treatment were researched respectively. Cost-benefit analysis of chemical-mechanical dewatering and subsequent sediment treatment has been performed as an example. The work in the study was aimed at providing reference for sustainable sediment management of urban lake systems in China.
\end{abstract}

Keywords: East Lake, polluted sediments, sediment management, bio-physical and socioeconomic approach, framework

\section{Introduction}

Sediment is a material, such as sand, silt, or clay, suspended in or settled on the bottom of a water body. Its

*e-mail: senlinzhu@whu.edu.cn input to a water body comes from natural resources such as erosion of soils and weathering of rocks, or as the result of anthropogenic activities such as forest or agriculture practice, or construction activities [1]. Water and sediment system is in a dynamic equilibrium in which sediment is in frequent and regular sedimentation and re-suspension in lakes [2]. Sediment is an intrinsic element, and it has ecological, social, and economic relevance. It is important 
Table 1. Current situations of large lakes in China.

\begin{tabular}{|c|c|}
\hline Region & Current situation \\
\hline East Lake & $\begin{array}{c}\text { Pollution, pollution of bottom sediment, } \\
\text { sedimentation }\end{array}$ \\
\hline Xuanwu Lake & $\begin{array}{c}\text { Eutrophication, pollution of bottom } \\
\text { sediment, sedimentation }\end{array}$ \\
\hline Dianchi Lake & $\begin{array}{c}\text { Eutrophication, pollution of bottom } \\
\text { sediment, sedimentation }\end{array}$ \\
\hline Dongting Lake & $\begin{array}{c}\text { Pollution of bottom sediment, shrinkage, } \\
\text { sedimentation }\end{array}$ \\
\hline Poyang Lake & $\begin{array}{c}\text { Pollution of bottom sediment, wetland } \\
\text { degradation, sedimentation }\end{array}$ \\
\hline Taihu Lake & $\begin{array}{c}\text { Eutrophication, pollution of bottom } \\
\text { sediment, sedimentation }\end{array}$ \\
\hline
\end{tabular}

from the perspective of ecology, because it is one of the key components of an aquatic ecosystem in lakes. It gives habitats and food resources for many organisms, and through the interaction with overlying water bodies it plays an essential role in aquatic ecosystems [3].

Lake sediments provide valuable records of natural environment and climate changes [4-6], geomagnetic variations [7-9], land-utilization within the watershed [10-11], and pollution caused by anthropogenic impacts within the lake catchment [12-14]. Particularly, lake sediment is a good collector of organic and inorganic contaminants (nutrients, toxic pollutants, and heavy metals). Anthropogenic sources of pollution in urban lakes basically comprise: 1) emissions from industrial and fossil fuel combustion processes (steel works and power generation), 2) particles from vehicles (exhaust particulates, brake lining dust, and body erosion), 3) exotic materials (metallic fragments, slag, road surface, and building materials), and 4) fertilizers and pesticides (mostly transported from agricultural soils) and sewage sludge. These contaminants are liable to pass through different food-chains in aquatic ecosystems and cause a health risks for humans.

In recent years, with the rapid development of urbanization in China, sedimentation and degradation of lakes have occurred and to some extent restricted sustainable development of local economies due to the neglect of effective protection and management of lakes. Numerous problems have occurred in such large lakes as Taihu in Jiangsu Province [15], Dianchi in Kunming City [16], Xuanwu in Nanjing City [17], East Lake in Wuhan City [18], Dongting in Hunan Province [19], and Poyang in Jiangxi Province [20]. Current situations in these lakes are presented in Table 1. It is clear that sedimentation and pollution of bottom sediments are the general characters of these lakes. In Dongting, due to severe sedimentation, lake areas have shriveled from $4,350 \mathrm{~km}^{2}$ to $2,700 \mathrm{~km}^{2}$, which severely affects local ecology. In Xuanwu, due to the impacts of human activities, serious pollution of bottom sediments (heavy metal contamination and nutrients) have occurred, making it burdensome for sustainable management [21]. In East Lake, the average sedimentary thickness has reached $1.06 \mathrm{~m}$ - up to one third of the average water depth - and the total sedimentation volume has reached 480 million $\mathrm{m}^{3}$ according to [22]. Huge sediment quantity and deteriorative sediment quality have significantly affected the East Lake ecosystem. In general, sedimentrelated problems have seriously affected regulation of these lakes. Thus, sediment management of lakes in China is especially urgent. Meanwhile, sediment management, acting as an important aspect of lake management, should get the attention it deserves. But so far, domestic research on this subject is almost blank. Sustainable sediment management overseas is mainly focused on basin scale in rivers [23].

In this study, sediment management in East Lake has been established. Framework for sediment management in polluted lake systems has been suggested. Based on the framework, sources of sediment and associated contaminants are analyzed, and the management methods, such as local dredging, bioremediation, and connection of six lakes and the Yangtze River are respectively being investigated. The sequent disposal of sediment (beneficial use) has been introduced. Meanwhile, benefit analysis of management methods is studied. This manuscript aims to provide reference for sustainable sediment management of lakes in China.

\section{Materials and Methods}

\section{Study Area}

East Lake, the largest urban lake in China, lies northeast of the city of Wuhan and is close to Wuhan Iron and Steel Company and Qingshan Thermal Power Plant, a heavy industrial district (Fig. 1). A large number of roadway dikes have been constructed across East Lake, dividing it into several distinct water bodies: Guozheng Lake and Tanglin Lake are the two major basins, and Shuiguo Lake, Guanqiao Lake and Miaohu Lake are relatively small basins. Inter-basin water exchange occurs only through bridge under-passes and culverts beneath the roadways. The water area and the average depth of the lake are, respectively, $27.9 \mathrm{~km}^{2}$ and 3-4 $\mathrm{m}$ with a maximum depth of $4.75 \mathrm{~m}$ [14].

East Lake was an open lake that was connected with the Yangtze River before 1957, when Wuhan Iron and Steel Company and Qingshan Thermal Power Plant were constructed. Since then, the lake was isolated from the Yangtze River and became an artificially controlled inland water body. With the rapid development of industrialization and urbanization, environmental pollution has been constantly increasing during the last decades. Urban expansion and industrial development around the lake began in the 1950s. At present, Qingshan Thermal Power Plant has a total capacity of $986,000 \mathrm{~kW}$, and Wuhan Iron and Steel Company is the third largest iron and steel consortium in China. In addition, further 


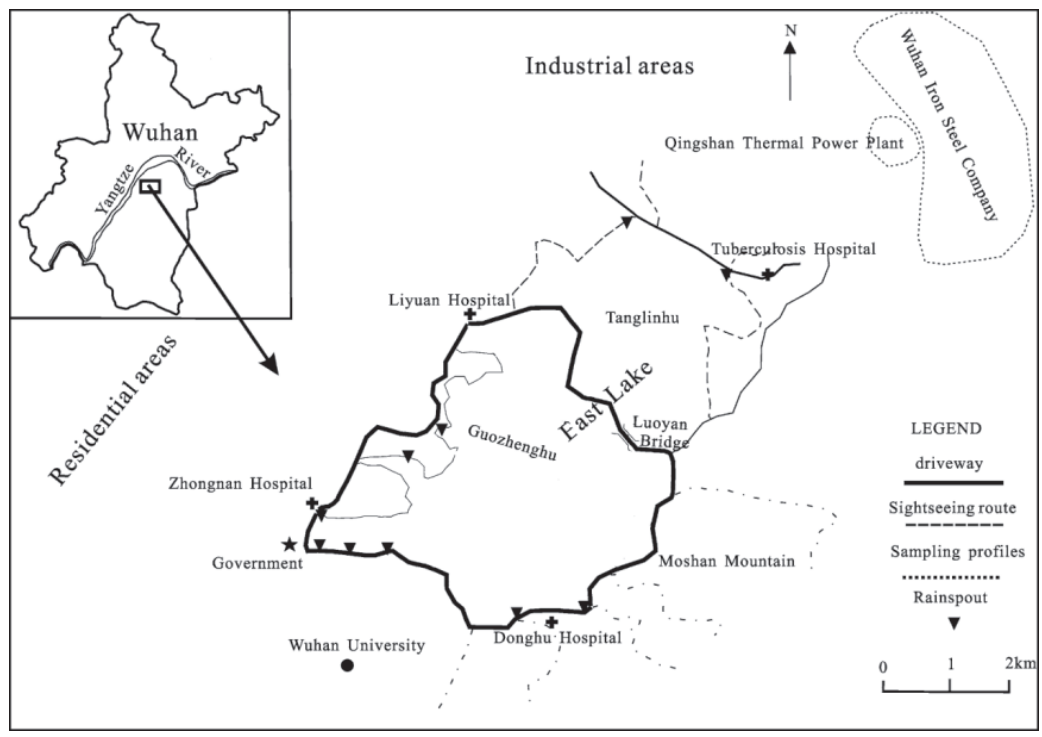

Fig. 1. Map of East Lake in the city of Wuhan.

industrial plants such as cement plants, foundries, coal gasification, and coking plants have been built in the Qingshan industrial area. Since then, a large amount of atmospheric particles generated by industrial processes such as combustion of coal for power generation, iron and steel production, and non-ferrous metal smelting have been deposited in the lake. Sometimes wastewater is released into the lake from industrial areas. Additionally, a large amount of wastewater enters the lake from residential districts and hospitals through many small outlets - especially the southwest shore of the lake.

\section{Sediment Management of East Lake}

Since the beginning of the industrial revolution, hazardous chemicals have been emitted to surface waters of lakes and rivers. Lots of these chemicals do not readily dissolve in water but rather adhere or accumulate into the sediment. Therefore, sediment acts as a sink for contaminants, and consequently sediment quality also has deteriorated because several chemicals do not readily degrade in sediments but accumulate instead. Sedimentation and pollution of bottom sediments brings about serious issues in the East Lake basin, such as deterioration of water quality, mortality of aquatic organisms (dead fish floating on the surface of lake water), and the poor tourism quality in the East Lake scenic area. Thus, sediment management in lake basins should be immediately carried out, with sediment quantity and sediment quality being considered simultaneously.

\section{Sediment Management Framework in Lakes}

In the process of lake management in China, technical governance has been chronically placed in the first

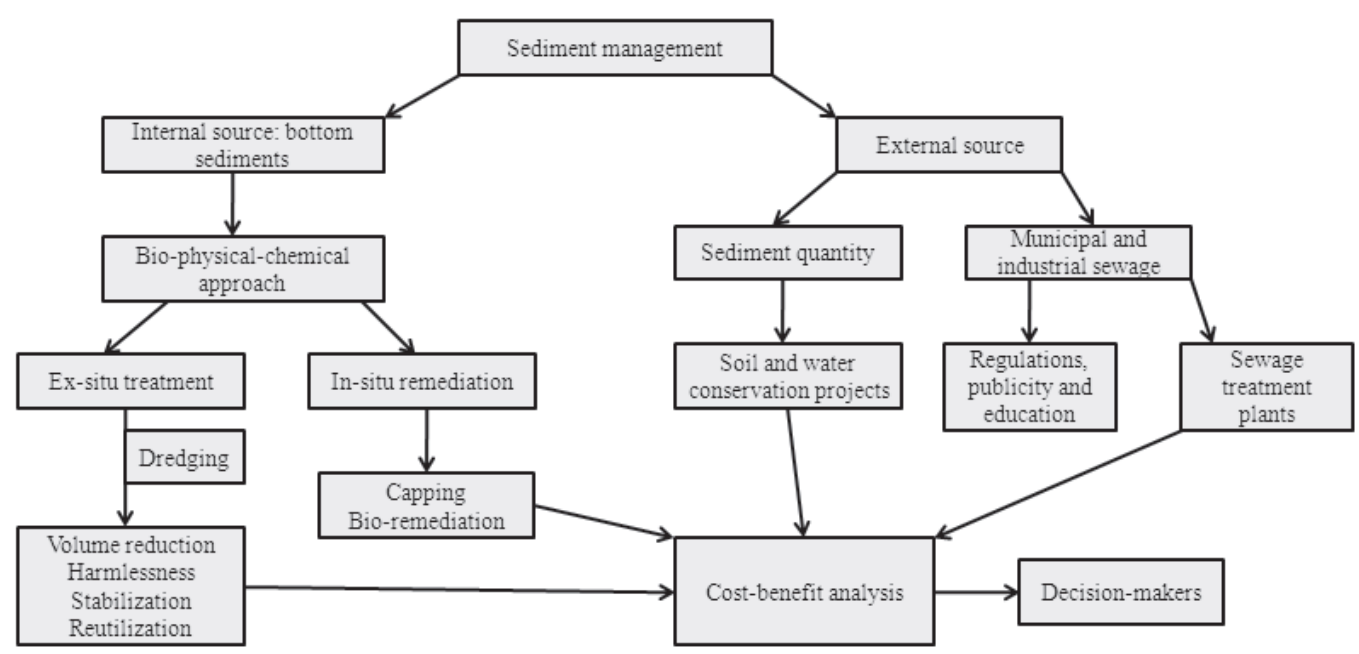

Fig. 2. Framework for sediment management of contaminated lake systems. 
place, management and protection has been neglected, and overall framework of lake protection has not been established [24], let alone sediment management framework for contaminated lake systems. According to our experience of lake management, lake management concept should be improved, and it is protection rather than exploitation and utilization of lake resources that should be concerned. Framework for sediment management in contaminated lakes is suggested (Fig. 2). External sources control should be a priority among priorities, and management of internal sources should be carried out simultaneously. Based on this, sediment management in East Lake has been established through: 1) sediment quality and quantity analysis, 2) relevant management methods, 3) subsequent sediment disposal, and 4) benefit analysis. Treatments have to be integrated into lake management and have to be sustainable. Sustainability means that environmental, economic, and social aspects must be integrated and interventions should not result in unwanted results elsewhere or any time in the lake basin. Thus, management methods should be sure to comply with the above requirements.

\section{Sediment Quality and Quantity Analysis}

Due to the rapid development of industrialization and urbanization, sedimentation rate in the lake becomes severe, and ranges from 2.1 to $7.8 \mathrm{~mm} \mathrm{a}^{-1}$ with an average of $4.6 \mathrm{~mm} \mathrm{a}^{-1}$ [14]. The basement of East Lake is entirely deposited with sediments. Sediment particle gradation (sampled from Miaohu Lake) can be seen in Fig. 3. The median sediment diameter is $3.73 \mu \mathrm{m}$, and the entire sediment belongs to a cohesive sediment such as clay and mud. Due to the strong viscosity, these settled sediments will easily absorb contaminants. Then bottom sediments will act as a sink for pollutants, and under certain conditions (wind, water disturbance), the absorbed sediments will be released into overlying water and cause secondary pollution. Thus, it is urgent to carry out sediment quality and quantity analysis in East Lake.

Sources of sediment and associated contaminants to East Lake are presented in Table 2, and non-point sources, such as erosion from rural, agricultural, and forested land and atmospheric deposition made a huge contribution. Sources of associated contaminants to East Lake are mainly point-sources, such as sewage
Table 3. Average concentrations of TP, TN, and COD in bottom sediments (mg/L).

\begin{tabular}{|c|c|c|c|}
\hline Lake area & TP & TN & COD \\
\hline Shuiguo Lake & 1.15 & 2.24 & 27.87 \\
\hline Guozheng Lake & 0.8 & 1.18 & 20.45 \\
\hline Tanglin Lake & 0.6 & 1.05 & 18 \\
\hline Miaohu Lake & 1.15 & 6.78 & 35.92 \\
\hline
\end{tabular}

discharge outlets across East Lake [25]. Total quantity of sewage effluent into the lake is $3.0 \times 10^{5} \mathrm{t} / \mathrm{day}$, and sewage discharge outlets account for 47 percent (data source: Wuhan Water Conservancy Bureau). The driveways along the shores and the sightseeing routes from Moshan Park to East Lake Park may also contribute to the input of pollutants into the lake. Since they are non-point sources, the total pollution load is hard to measure. Transported particles from Wuhan Iron and Steel Company and Qingshan Thermal Power Plant are considered to be a significant contribution of pollutants, and the total dust emission load is $30 \mathrm{t} / \mathrm{km}^{2}$ per month. Since they are close to the northeast of the study area, the prevailing winds (northerly and northeast mistrals) allow for the southward and southwest-ward atmospheric transport of pollutants.

Affected by municipal wastewater from the sewage discharge outlets and industrial wastewater from Qingshan industrial area, permanganate potassium, BOD, TN, and TP are over-discharged, and Shuiguo, Miaohu, and Guozheng lakes (sub-domains of East Lake) are eutrophied to some extent. Average concentrations of $\mathrm{TP}, \mathrm{TN}$, and COD in bottom sediments in sub-domains of East Lake are presented in Table 3 [26]. Therefore, measures should be taken to treat polluted sediment and associated contaminants rapidly.

\section{Management Methods}

Source control is the prerequisite to reach a sediment quality and quantity standard that does not pose a risk to aquatic systems or upland use. Investments in source control are often more economical than other treatment projects in lake areas and it can always be considered as sustainable and important to improve the sediment quality and reduce sediment quantity. In addition, based

Table 2. Sources of sediment and associated contaminants in East Lake.

\begin{tabular}{|c|c|}
\hline Material & Sources \\
\hline Sediment (organic and inorganic) & $\begin{array}{r}\text { Erosion from rural, agricultural, and forested land; lake banks; urban road dust; } \\
\text { sewage treatment plant solids; atmospheric deposition }\end{array}$ \\
\hline Metals (Cu, Co, Cr, Ni, Pb, Zn, Fe) & $\begin{array}{c}\text { Geology, industry (Wuhan Iron Steel Company, Qingshan Thermal Power Plant), } \\
\text { municipal wastewater, sewage treatment, urban runoff, agricultural runoff (fertilizer) }\end{array}$ \\
\hline Nutrients (N, P) & Agricultural and urban runoff, wastewater and sewage treatment \\
\hline $\begin{array}{c}\text { Organic compounds (pesticides, herbicides, } \\
\text { hydrocarbons) }\end{array}$ & Agriculture, industry, sewage, landfill, urban runoff \\
\hline
\end{tabular}




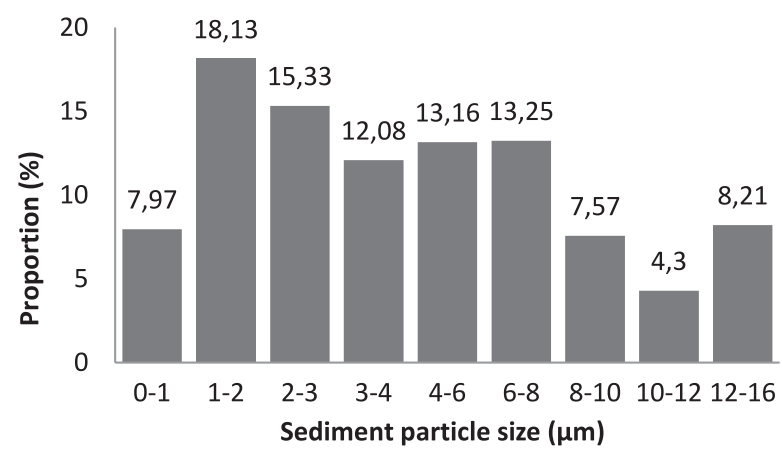

Fig. 3. Sediment particle gradation (sampled from Miaohu Lake).

on source control, local dredging has been applied in some highly contaminated lake areas. Bioremediation of highly contaminated sediments has been established as a pilot project in East Lake.

In 1957 East Lake was isolated from the Yangtze River and became an inland water body. Due to the construction of gates and dams, river-lake relations (between the Yangtze and urban lakes in the city of Wuhan) have been interrupted artificially. Since then, the natural modulation function of East Lake (water quantity regulation and self-purification capacity) has been weakened, which to some extent resulted in water quality deterioration in East Lake. Thus, from the perspective of ecology and the environment, the thought of connecting six lakes and the Yangtze has been proposed to restore river-lake relations. Bringing in clear water from the Yangtze to purify lake water and form a dynamic water environment in lake basins can, to some extent, improve water quality conditions and reduce sediment quantity (dilution and degradation of pollutants).

\section{Source Control}

Sources of sediment to East Lake are mainly nonpoint sources, such as erosion from rural, agricultural, and forested land. Water and soil conservation projects,

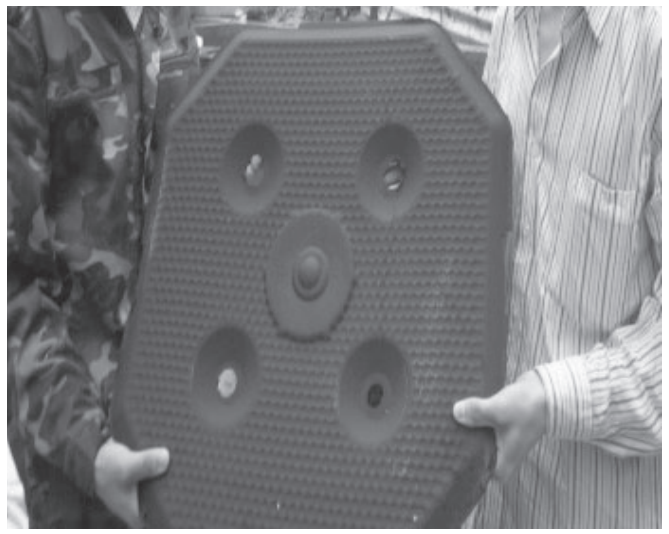

Fig. 5. Sediment cake from East Lake.

such as planting herbs and sediment trapping dam, should be carried out in these areas.

The main contaminated sources to the lake are municipal and industrial sewage, especially sewage discharge outlets across the lake. In order to intercept wastewater, 34 sewage discharge outlets across the lake have been treated and been partially closed. Large sewage emission outlets have been connected with nearby sewage treatment plants. Nine new sewage treatment plants have been constructed along the lake basin - especially the industrial area. Thus, wastewater from the industrial area in Qingshan and municipal pollutants around the lake basin can be controlled and treated rather than directly discharged into the lake. Moreover, regulations of pollution control have been developed for pollution management around East Lake. Local community involvement was improved in past years, with municipal wastewater and garbage being reasonably managed rather than directly discharged into the lake.

Non-point sources of associated contaminants are those originating from a wide area in the lake basin. As a result, the identification and in particular the control of these sources presents much more of a challenge to sediment management. However, given the high level

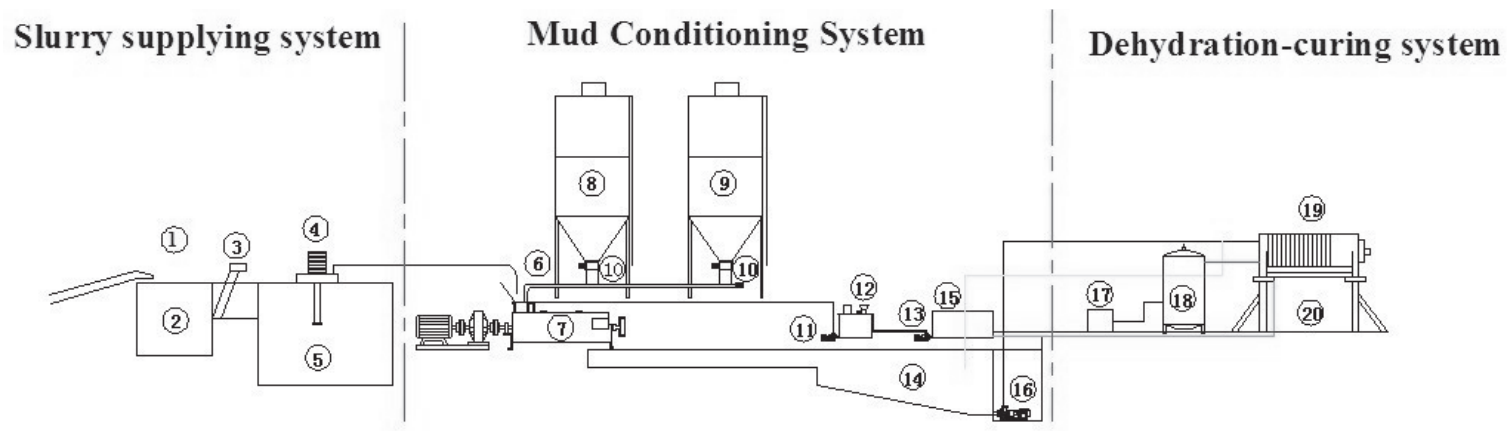

(1)Pipeline(2)Sedimentation tank(3)Grill machine(4)Vertical pumps(5)Slurry storage tank(6)Conveying Machine (7)Blender (8) Sediment coagulation agent (9)Mud curing agent(10)Unloader (11)Pump(12)Dispensing Machine(13)Pump (14)Homogenized pool (15)Clean water tank (16F Feeding Pumps(17)Air Compressor (18) Cylinders(19)Filter Press (20) Belt conveying machine

Fig. 4. Process of dredging and consolidation method. 
of success in controlling point sources of sediment and associated contaminants, these non-point sources are now recognized as requiring the most effort for identification and control. The driveways along the shores and the sightseeing routes from Moshan Park to East Lake Park are the main contributors to the input of nonpoint pollutants into the lake. According to the existing research results, engineering measures such as polyporous pavement, retention ponds, constructed wetlands and green buffer, and non-engineering measures such as urban environmental management and pavement sweeping can be adopted to manage the non-point sources in these areas. These engineering measures will increase environment diversity in the East Lake scenic area and bring benefits to local residents simultaneously.

\section{Local Dredging}

Sediment quantity has been managed for centuries, mostly by dredging. Dredging is necessary to allow all the uses of East Lake water system (maintenance), but also for remediation, whereas the risk for the environment and health might be high. Local dredging has been applied to maintain highly contaminated lake areas. In East Lake basin, local dredging is utilized for managing Miaohu Lake and Guanqiao Lake, both sub-domains of East Lake. Due to long-term acceptance of surrounding wastewater, Miaohu and Guanqiao lakes have been seriously polluted and a bad smell befouls the atmosphere throughout the year, which seriously and adversely affects nearby residents.

It is not possible for dredged sediments to be dehydrated and dried rapidly using the widely studied natural dewatering and drying method [27]: dewatering efficiency is low, processed sediments are easily muddy, processing period is long, and pollution has the risk of migration. Based on this, the technique of chemicalmechanical dewatering is proposed (Award for Scientific and Technological Advancement in Hubei Province, Wuhan University, Guolu Yang). A detailed process of the technique is shown in Fig. 4.

In total, about $1 \mathrm{mln} \mathrm{m}^{3}$ of sediments have been dredged in these 2 sub-domains. Sediment particle gradation is presented in Fig. 3. The dredged sediments will be discharged immediately into a mud-conditioning system, and with the effect of sediment coagulation agent (adjusting sediment properties), mud curing agent (fly ash, cement, and lime), and plate-and-frame filter press (dewatering), sediment-cake with a certain intensity and low water content $(35 \%)$ will be produced, as shown in Fig. 5.

The whole dewatering process can be completed in 45 minutes, and it also enables proper control of the dewatering process. The process yields an end product of superior quality, and hence opens up new opportunities for re-use and recycling. Meanwhile, it meets volume reduction, harmless disposal, stabilization, and reutilization of dredged sediments. The technique brings convenience to the sequent transport and beneficial use of

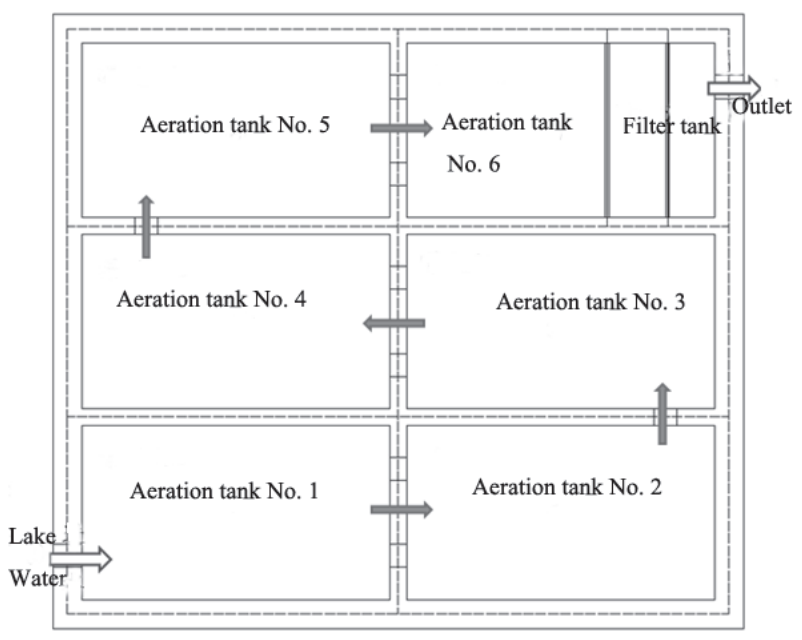

Fig. 6. Diagram of bio-membrane remediation technique.

dredged sediments, and has been widely applied in China (in Shahu Lake, East Lake, Huangxiao River, Dianchi Lake).

\section{Bioremediation}

Bioremediation of sediment and associated contaminants is an effective in-situ remediation technology, and it has been applied as a pilot project in East Lake. This study uses the bio-membrane remediation technique. Aquatic micro-organisms will attach to the surface of the medium and produce bio-membrane. When wastewater comes into contact with bio-membrane, organic contaminants will be absorbed and degraded into water, carbon dioxide, and ammonia by microorganisms, and water will be purified.

In the East Lake basin, bioremediation was utilized to manage Miaohu Lake, a sub-domain of East Lake. The remediation work mainly consists of a bio-filter tank and fixed bio-membrane remediation tank (Fig. 6). Through analysis of samples from the inlet and outlet locations, COD, TN, and TP were measured (Fig. 7). It can be observed that with the bio-membrane remediation technique, contaminants in the lake can be degraded enormously and sediment quantity can be reduced

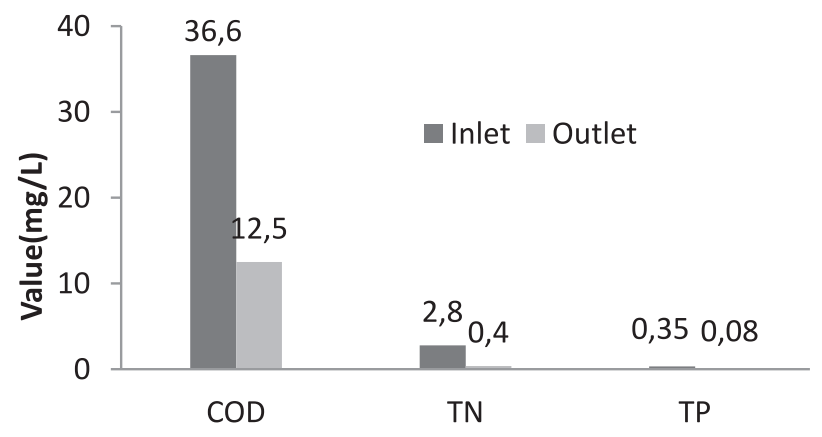

Fig. 7. Comparison of COD, TN, and TP between inlet and outlet water. 


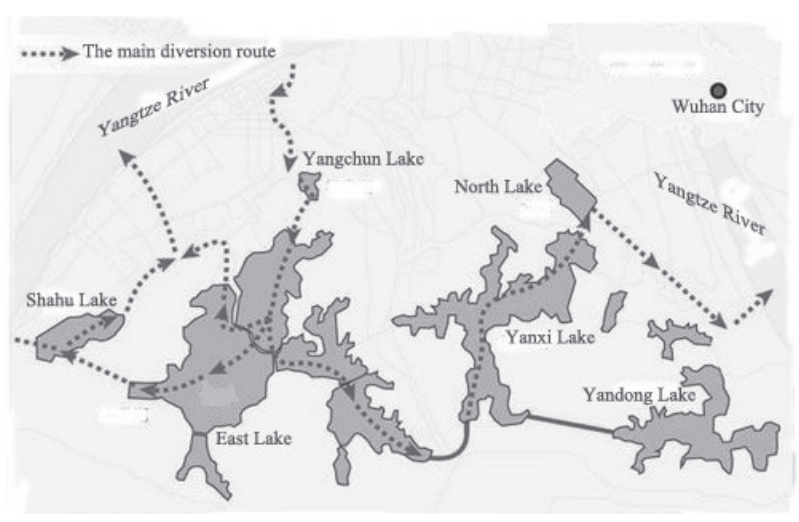

Fig. 8. Sketch map of connecting six lakes with the Yangtze River.

simultaneously. Water quality level varied from $\mathrm{V}$ in the inlet to II (as defined by Environmental Quality Standards for Surface Water in China, GB 3838-2002) in the outlet, and water quality conditions have been effectively improved. Clearly, it can be concluded that with the utilization of the bio-membrane remediation technique, sediment quantity and associated contaminants can be reduced enormously. Then the technique can be promoted in the East Lake basin.

\section{Connecting Six Lakes and the Yangtze River}

Connecting six lakes and Yangtze River is a huge ecological water network. The six lakes are, respectively, East, Shahu, Yandong, Yanxi, Yangchun, and North (Fig. 8). The total area of these lakes is $62.6 \mathrm{~km}^{2}$, with East Lake accounting for $44.6 \%$, and total capacity of water bodies 0.2 billion $\mathrm{m}^{3}$, with East Lake accounting for $60.0 \%$. The main purpose is to bring in clear water from the Yangtze to purify lake water, form a dynamic water environment in the lake basins, and restore riverlake relations. A sluice gate will be set in the connection points of lake-lake and lake-Yangtze in order to facilitate the operation.

Monitoring stations will be established in these lake basins (mainly in East Lake), and water quality index (COD, TN, and TP) will be measured in a timely way. Real-time monitoring data will be sent to a data acquisition center for further steps by decision makers. At the present stage, this project is in its infancy, and connection work is gradually being carried out. Currently, Shahu Lake and East Lake have been connected. Meanwhile, mathematical and physical models have been used to predict water quality conditions in lake basins [28-30]. The results indicate that East Lake, acting as a receiving water-body of the Yangtze, will enhance its fluidity and self-purification properties and improve its water quality conditions - especially in the still boundary water areas. The associated contaminants absorbed by sediments will be degraded (dynamic water environment increases re-aeration capacity of water body), and bottom sediment quantity will be reduced simultaneously in East Lake. Meanwhile, the state of the water body has been changed from isolated to a dynamic circulating water system, and retention time of contaminants and polluted sediments in lake basins can be greatly reduced. In the long run, connections of lakes and the Yangtze will play a significant role in the remediation of the lake ecosystem.

\section{Sequent Sediment Disposal}

In the East Lake basin, dredged sediment is contaminated by human activities (industrial and municipal sewage) to the extent that major environmental constraints need to be applied when depositing these sediments. Some of these sediments are contaminated so heavily that this material has to be treated before the products can safely be brought back into the environment. This processing or treatment of the sediments raises costs and is a burden for society. Therefore, beneficial use of these sediments is particularly important.

In the East Lake basin, dredged sediments are processed into sediment cakes. For beneficial use, common pathogenic microorganisms, heavy metals, and the $\mathrm{pH}$ of these processed cakes are respectively being measured on the basis of specified regulations, and the detailed results are presented in Table 4. It can be concluded that measured results of the above indicators all meet the environmental quality standards of soil and

Table 4. Detailed measured results of sediment cakes.

\begin{tabular}{|c|l|c|c|}
\hline Test items & Detection method & $\begin{array}{c}\text { Maximum allowable } \\
\text { emission value }\end{array}$ & $\begin{array}{c}\text { Measured } \\
\text { value }\end{array}$ \\
\hline $\mathrm{pH}$ & Modern analysis methods of soil elements & $/$ & 7.52 \\
\hline Cadmium $(\mathrm{mg} / \mathrm{kg})$ & Modern analysis methods of soil elements & 1 & 0.48 \\
\hline Copper $(\mathrm{mg} / \mathrm{kg})$ & Modern analysis methods of soil elements & 400 & 340 \\
\hline Lead $(\mathrm{mg} / \mathrm{kg})$ & Modern analysis methods of soil elements & 500 & 290 \\
\hline Chrome $(\mathrm{mg} / \mathrm{kg})$ & Modern analysis methods of soil elements & 400 & 131 \\
\hline Zinc $(\mathrm{mg} / \mathrm{kg})$ & Modern analysis methods of soil elements & 500 & 82.1 \\
\cline { 1 - 4 } Common pathogenic microorganisms \\
(number/g)
\end{tabular}


will not harm the environment, and these processed cakes can safely be brought back into the environment.

Referring to beneficial use, these sediment cakes can be used in many fields, such as shoreline remediation, organic fertilizer, backfill soil, and building materials. The treated cakes have been utilized to remediate shoreline, and good social benefits have been achieved in the sediment treatment project of East Lake. Also, sediment cakes have been used as greening soils in Shahu Park. It has been measured that the unconfined compressive strength of these cakes can reach $140 \mathrm{KPa}$, which is larger than the foundation-bearing capacity requirement of $80 \mathrm{KPa}$ (Building Foundation Design Code GB 50007-2011). Thus, it can be directly used as foundation soils. Meanwhile, cakes can be burned to generate power if content of organic matter is large. Currently, the technique of sludge incineration for generating power is mature, and it has been widely applied in Guangdong Province, with further promotion possible in the city of Wuhan.

\section{Benefit Analysis}

This part analyzes beneficiary customers of sediment management. Based on this, sources of funds for lake management are studied. Benefit analysis of the above management methods is also analyzed.

\section{Beneficiary Customers}

Many organizations are distributed around East Lake: the provincial government of Hubei Province; institutions of higher education such as Wuhan University, the Wuhan Institute of Physical Education, China University of Geosciences, and Huazhong University of Science and Technology; research institutions such as the Research Institution of Aquatic Organisms in the Chinese Academy of Sciences; scenic areas such as East Lake Park, Liyuan Park, Moshan Park, and Wuhan Botanical Garden; hospitals such as Zhongnan Hospital of Wuhan University, Liyuan Hospital, Geriatrics Hospital in Hubei Province, and East Lake Hospital; Qingshan industrial area, including Qingshan Thermal Power Plant and Wuhan Iron and Steel Company; and residential areas such as Shuiguo Lake, East Lake Village, East Lake Bridge, and Liyuan communities. Effective sediment management in East Lake can build a good living and working environment for the above organizations. With better water quality conditions (foul smell no longer exists, dead fish no longer float, and clear water) in East Lake, many recreational activities can be carried out, such as swimming, boating on the lake, angling, sightseeing, jogging along the lake side, aquatic entertainment projects, and traveling for pleasure. In summary, beneficiary customers are numerous, mainly for the above organizations. Tourists from other places may also benefit.

\section{Sources of Funds}

For any management projects, sources of funds are a priority among priorities, especially for such large projects as lake management. In the sediment management project of East Lake, the funds mainly came from national government, which however, is inadequate. Based on the regulation that whoever causes pollution is responsible for its treatment and whoever benefits from it is responsible for its compensation, other sources of funds can be confirmed: 1) pollution administration fees from Qingshan industrial area, mainly Qingshan Thermal Power Plant and Wuhan Iron and Steel Company; 2) pollution compensation from residents around East Lake; and 3) a small portion of management fees from tourists. In addition, the management experience of Shahu Lake can be followed. Wanda Group invested $\$ 8.3$ billion US in this project, and successful sediment management of Shahu Lake and the connection between Shahu and East lakes has been realized. The Chu River and Han Street feature world-class historical culture and ecological landscape engineering, including tourism, business, commerce, and inhabitancy. The economic benefit is significant. Based on this, sources of funds can be further broadened by attracting business investment in sediment management in East Lake.

\section{Benefit Analysis of Management Methods}

Source control can fundamentally solve the problem of sedimentation and lake pollution. Investments in source control are often more economical than other treatment projects in lake areas. Water and soil conservation projects such as planting herbs will simultaneously increase biodiversity in scenic areas around East Lake. The newly built sewage treatment plants have seen large investment (\$0.16 billion for three sewage treatment plants: Shahu, Erlangmiao and Longwangzui, with a daily processing capacity of 380,000 t, Wuhan Water Conservancy Bureau) can also be used to dispose of other wastewater, and will benefit ecological construction in Wuhan in the long run.

Connecting lakes with the Yangtze River has been proven to be effective in sediment management in lakes according to the simulation results of physical and mathematical models. Constructing a dynamic water environment in lakes can increase self-purification capacity of water bodies, and restoring river-lake relations will play a significant role in the remediation of the lake ecosystem, as was indicated in the development of the water diversion project from the Yangtze to manage Taihu Lake [31]. Currently, a successful connection of East Lake and Shahu Lake has been achieved (investment: $\$ 0.62$ billion, Wuhan Water Conservancy Bureau). The Chu River and Han Street have proven to be especially successful, whether for the development of the local economy or sediment management in lakes. Subsequent connection works should proceed slowly.

Local dredging and bioremediation are suitable for small-scale projects, and they have an obvious effect in 
Table 5. Cost-benefit analysis of chemical-mechanical dewatering $\left(\$ / \mathrm{m}^{3}\right.$ sediment $)$.

\begin{tabular}{|c|c|c|}
\hline \multirow{2}{*}{$\begin{array}{c}\text { Economic } \\
\text { benefit }\end{array}$} & $\begin{array}{c}\text { Technology, material, equipment, and } \\
\text { labor cost }\end{array}$ & 9.7 \\
\cline { 2 - 3 } & Reduction of land occupation & 233 \\
\cline { 2 - 3 } & Building materials & 2.5 \\
\hline \multirow{2}{*}{$\begin{array}{c}\text { Ecological } \\
\text { benefit }\end{array}$} & Water conservation & 0.1 \\
\cline { 2 - 3 } & Biodiversity & 0.15 \\
\hline
\end{tabular}

the short term. However, for sediment management in large lakes such as East Lake, they are mainly used to manage such severely contaminative sub-domains as Miaohu Lake (investment: \$1.0 million, Wuhan Water Conservancy Bureau). Here, cost-benefit analysis for the chemical-mechanical dewatering method is adopted as an example (Table 5).

Total sediment treatment cost (technology, material, equipment, and labor) is $9.7 \$ / \mathrm{m}^{3}$. The benefit of reducing land occupation by dredged sediments can be assessed with the substitute expense method. Referring to the data of Taihu Lake sediments, land occupation is $0.334 \mathrm{~m}^{2}$ for one $\mathrm{m}^{3}$ dredged sediment. Nationwide average comprehensive land value in key cities is $700 \$ / \mathrm{m}^{3}$ (Urban Land Price Report in China), and then the benefit of reducing land occupation is $233 \$$ / $\mathrm{m}^{3}$. The benefit of water conservation can be obtained based on reservoir construction $\left(0.1 \$ / \mathrm{m}^{3}\right)$. Benefit of biodiversity is $400-1,400 \$ / \mathrm{hm}^{2}$. Here, $1,400 \$ / \mathrm{hm}^{2}$ is selected, and then the benefit of biodiversity is $0.15 \$ / \mathrm{m}^{3}$. Other environmental benefits, such as pollution reduction for surface and groundwater, have not been assessed in this study. Generally, in the chemicalmechanical dewatering project in East Lake, economic and ecological benefits are much larger than total cost, and good ecological and social benefits have been observed.

\section{Conclusions}

Severe sedimentation and pollution of bottom sediments has occurred in large urban lakes in China, and sediment management should be carried out in lake systems as an important aspect of lake management. In this study, sediment management in East Lake was established as an example, and the main work with some conclusions can be summarized as follows:

1) Sediment quality and quantity was analyzed, and the sources of sediment and associated contaminants were researched. It was concluded that sediment quality (heavy metals, $\mathrm{N}$ and $\mathrm{P}$ ) and quantity issues (huge sediment volume) were serious.

2) Potential sediment risk was assessed, and it was found that sediment-related issues brought problems to surrounding residents in terms of odor and aesthetics. The release of $\mathrm{P}$ would cause secondary pollution to the overlying water-body, and heavy metals posed a potential ecological risk.

3) Sediment management methods such as ecological water network, source control measures (sewage interception engineering, sewage treatment plants), and the chemical-mechanical dewatering method for local dredging were respectively studied, and subsequent sediment disposal and beneficial use of the processed sediment cakes were introduced. Cost-benefit evaluation, together with analysis of beneficiary customers and fund sources, indicated that the management methods met the requirements of "sustainability" well.

4) Source control measures were considered as the foundation of the management process. Local dredging and the ecological water network were effective for managing sediment-related issues, and the monitoring and evaluation platform provided a tool for scientific operation and long-term management of the lake system. Based on this, the sediment management framework for contaminated urban lake systems could be developed. The whole process of sediment management in East Lake shows a high level of sustainability, and the work in the study is believed to provide reference for sustainable sediment management of urban lake systems in China.

\section{Acknowledgements}

This work was mainly funded by the National Key R\&D Program of China (2016YFC0401506), the program of International S\&T Cooperation of China (2015DFA01000), and the Projects of National Natural Science Foundation of China (51679146; 51479120; 51479121), and Natural Science Foundation of Jiangsu Province (BK20141075).

\section{References}

1. HASSAN M., RAHMAN M.A.T.M, SAHA B., KAMAL A.K.I. Status of Heavy Metals in Water and Sediment of the Meghna River, Bangladesh. American Journal of Environmental Sciences. 11, 427, 2015.

2. YANG C.T. Sediment Transport, River Morphology, and River Engineering. Handbook of Environmental Engineering. 15, 339, 2014.

3. BO L.J., WANG D.J., LI T.L., LI Y., ZHANG G., WANG C., ZHANG S.Q. Accumulation and risk assessment of heavy metals in water, sediments, and aquatic organisms in rural rivers in the Taihu Lake region, China. Environmental Science and Pollution Research. 22, 6721, 2015.

4. FRANK U. Rock magnetic studies on sediments from Erlongwan maar lake, Long Gang Volcanic Field, Jilin province, NE China. Geophysical Journal International. 168, 13, 2010.

5. COURTY M.A., VALLVERDU J. The microstratigraphic record of abrupt climate changes in cave sediments of the Western Mediterranean. Geoarchaeology-an International Journal. 16, 467, 2010. 
6. KANDASAMY S., LIN B.Z., LOU J., XIA W.L., HUANG X.T., CHEN C.A. Lacustrine sedimentological and geochemical records for the last 170 years of climate and environmental changes in southeastern China. Boreas. 45, 165, 2016.

7. FRANK U. Palaeomagnetic investigations on lake sediments from NE China: A new record of geomagnetic secular variations for the last $37 \mathrm{ka}$. Geophysical Journal International. 169, 29, 2010.

8. CREER K.M., VALENCIO D.A., SINITO A.M., TUCHOLKA P., VILAS J.F.A. Geomagnetic Secular Variations 0\&Ndash;14 000 Yr Bp As Recorded By Lake Sediments From Argentina. Geophysical Journal of the Royal Astronomical Society. 74, 199, 2010.

9. HYODO M., MINEMOTO S. Paleomagnetic Dating Using Geomagnetic Secular Variations and Excursions from Lake Sediments in Japan. Quaternary Research. 35, 125, 2009.

10. PORAJ-GÓRSKA A.I., ŻARCZYŃSKI M.J., AHRENS A., ENTERS D., WEISBRODT D., TYLMANN W. Impact of historical land use changes on lacustrine sedimentation recorded in varved sediments of Lake Jaczno, northeastern Poland. Catena. 153, 182, 2017.

11. BICHET V., GAUTHIER E., MASSA E., PERREN B.B. Lake Sediments as an Archive of Land use and Environmental Change in the Eastern Settlement, Southwestern Greenland. Journal of the North Atlantic. sp6, 47, 2014.

12. HU S., WANG Y., APPEL E., ZHU Y., HOFFMANN V., SHI C., YU Y. Magnetic responses to acidification in Lake Yangzonghai, SW China. Physics and Chemistry of the Earth, Parts A/B/C. 28, 711, 2003.

13. JORDANOVA D., HOFFMANN V., FEHR K.T. Mineralmagnetic characterization of anthropogenic magnetic phases in the Danube River sediments (Bulgarian part). Earth planet. 221, 71, 2004.

14. YANG T., LIU Q.S., CHAN L.S., LIU Z.D. Magnetic signature of heavy metals pollution of sediments: case study from the East Lake in Wuhan, China. Environ. Geol. 52, 1639, 2007.

15. OTTEN T.G., XU H., QIN B., ZHU G., PAERL H.W. Spatiotemporal patterns and ecophysiology of toxigenic microcystis blooms in Lake Taihu, China: implications for water quality management. Environmental Science \& Technology. 46, 3480, 2012.

16. REN J.Q., MAO X.C., ZOU P.J. Simulation and Prediction on Space-Time Distribution of Water Quality in Dianchi Lake. Open Journal of Modern Hydrology. 3, 50, 2013.

17. LIU G.L., ZHANG L.C., HE B., JIN X., ZHANG Q., RAZAFINDRABE B., YOU H.L. Temporal changes in extreme high temperature, heat waves and relevant disasters in Nanjing metropolitan region, China. Natural Hazards. 76, 1415, 2015.

18. DING L., CHEN K.L., CHENG S.G., WANG X. Water ecological carrying capacity of urban lakes in the context of rapid urbanization: A case study of East Lake in Wuhan. Physics \& Chemistry of the Earth Parts A/B/C. 89-90, 104, 2015.

19. HAN Q., ZHANG S., HUANG G., ZHANG R. Analysis of Long-Term Water Level Variation in Dongting Lake, China. Water. 8, 306, 2016.

20. ZHI H., ZHAO Z., ZHANG L. The fate of polycyclic aromatic hydrocarbons (PAHs) and organochlorine pesticides (OCPs) in water from Poyang Lake, the largest freshwater lake in China. Chemosphere. 119, 1134, 2015.

21. ZHAO D.Y., MA T., ZENG J., YAN W.M., XU Y.N., JIANG C.L. Study on eutrophication and heavy metal pollution of Xuanwu Lake. Journal of Hohai University (Natural Sciences). 1, 83, 2012.

22. MENG Q.S., YANG C., LEI X.W., SUN S.L. Experimental study on early strength and stabilization of mud in East Lake in Wuhan. Journal of Rock and Soil Mechanics. 3, 707, 2010.

23. OWENS P. Conceptual models and budgets for sediment management at the river basin scale. Journal of soils and sediments. 5, 201, 2005.

24. MENG D.K. Lake management without protection can only be in vain. Southern Weekly. 2011.

25. WANG Z.Z., JIN J.L., ZHANG L.L. Intelligence method for recognizing pollutant sources in East Lake. Advances in Water Science. 5, 714, 2006.

26. WANG C.Y., PENG H., ZHANG W.S., LI Z.J. Analysis on TMDL plan for water pollution control of East Lake. Yangtze River. 10, 86, 2010.

27. DAI D.L., HE S.B., CHEN X.C., YANG F.F. Advances in Research on Dewatering and Drying of sediment sludge from lakes' and reservoir' environmental dredging. Water Purification Technology. 31, 80, 2012.

28. YANG G.L., LU J., ZHANG Y.J., LUO X. Connection, circulation, integration and harmony management strategy about water environment of East Lake Water Network Project. China Water Resources, 24, 2013.

29. ZHAO Y.X., ZHANG W.S., WU J., WANG Y. Numerical simulation of water diversion to improve the water quality of East Lake in Wuhan city. Resources and Environment in the Yangtze Basin. 2, 168, 2012.

30. YU C., REN X.Y., BAN X., DU G. Application of two-dimensional water quality model in the project of the water diversion in East Lake, Wuhan. Journal of Lake Sciences. 24, 43, 2012.

31. ZHOU X.P., ZHAI S.H., YUAN L. Influence of water diversion from Yangtze River to Taihu Lake on water quality of Taihu Lake between 2007 and 2008. Water Resources Protection. 1, 40, 2010. 